\title{
Communication Networks on Adopter Farmers of Planting Technology at Cigasong Districts in West Java
}

\author{
VIVIT WARDAH RUFAIDAH \\ ASEP SURYANA \\ DADANG SUGIANA \\ TUHPAWANA SENDJAJA \\ Universitas Padjadjaran, Indonesia
}

\begin{abstract}
The process of adopting technology "Jarwo", in addition to the influence of external factors, is also influenced by internal factors, namely the structure of communication network. This research is ai med at analysing the structure of communication network and identifying the role of actors in the communication network of the farmers as the adopter of technology Jarwo. This research was conducted in Cigasong Subdistrict, West Java Province. Research method uses the survey method and data is analysed using communication network analysis. Population determination uses a nominalist approach. Sampling technique uses a small group of samples with a population of 131 farmers. Analysis uses a complete networks analysis consisting of three levels of measurement, i.e. actor level, system level and group level and data processing uses UCINET VI. The results of this research showed that: The structure of the communications network for the farmers adopting technology Jarwo has a low level of cohesiveness; the size of the network is relatively large; the level of tissue density is low; network structure is decentralised; and average distance between fellow actors is quite high, and actors who play an important role in "event information sources" Jarwo is actor \#62 (agricultural extension) and \#42 who are farmers as betweenness; on "Discussion Events" Jarwo, actor \#235 who is an actor with centrality levels and high betweenness. This shows that the farmers adopting technology Jarwo prefer to discuss technology Jarwo with fellow farmers and informant neighbours.
\end{abstract}

Keywords: Communication network, farmers, innovation, agricultural technology, Jajar Legowo.

\section{INTRODUCTION}

One of the indicators of the success of Agricultural Technology Assessment Program is how much the results of the assessment are adopted by users (especially farmers) to apply it to farming activities. The right method of communication in the process of delivering agricultural innovation technology to farmers and stakeholders is a key to the success and sustainability of the food security program. The results of the research/assessment will benefit the farmers when the technology components produced are applied to the farmers in the management of land business. Therefore, information on the results of research/assessment needs to be communicated/disseminated both to intermediate user and end-user, through various communication strategies in both interpersonal and intrapersonal communication such as counselling methods and media information that will be used as a supporter of agricultural extension activities in the region and ultimately help farmers increase the efficiency in managing the farming business.

In a communication perspective, there are three main components that need to be considered in relation to the process of delivering agricultural technology information (Rogers \& Shoemaker, 1987). The three components are: (1) Source of information, namely researchers - the extension that is actively involved in the research and analysis activities 
(research-assessment); (2) Message/information to the prospective user; and (3) the media/channel (channel) used to convey the information. So far, the dissemination study has focused more on the dissemination process. In this study, the novelty of the research is based on the structure of the farmer's network based on interpersonal communication.

Dissemination of agricultural innovation research results is a communication activity that includes three main components of communication that are important in encouraging the process of deploying and implementing technology in a rural social system (Indraningsih, 2018). According to Syakir (2016), technological innovations produced by the Agricultural Research Department of the Agriculture Ministry have yet to be adopted properly on broad scale. This suggests that the innovation supply chain segment in the delivery subsystem and the receiving subsystem is a bottleneck that causes a lack of information delivery and low adoption rate as shown in the innovation produced by the Indonesian Agency for Agricultural Research and Development (IAARD) (Indraningsih, 2018).

The innovation of rice-planting technology Jajar Legowo ("Jarwo") is one of the superior innovations produced by IAARD and is one of the innovative approaches in the efforts to increase the efficiency of rice farming. The principle of Jarwo is to increase the crop population by adjusting planting distances in such way that cropping will have a row of plants that are interspersed by empty rows where there is the planting distance in the periphery of half the planting distance between the lines.

Jarwo's cropping system technology has contributed to the increase in rice production in West Java. The results of the study conducted by BB Padi (2014) mention the realisation that technology Jarwo raised rice productivity by 1.33 tons/ha. Jarwo has been introduced to farmers throughout Indonesia. It is mostly introduced in West Java Province where 402,710 ha of rice field have applied Jarwo each year or $43.65 \%$ of the total area of rice field in the province (BB Padi, 2014). The application of Jarwo's components can contribute to a $18.7 \%$ increase in yield.

In disseminating the innovation of planting technology Jarwo, the Ministry of Agriculture utilises SDMC (Spektrum Diseminasi Multi Channel) in the framework of diffusing the innovation among farmers. The dissemination of information about Jarwo done until now by the Ministry of Agriculture is formal, starting from utilizing: (1) Source of information derived from central and local institutions with its socialization done from the central level, district level to the farmer group; (2) A message that is the information of Jarwo and dissemination through various channels (3) media channels such as seminar meetings, lectures, discussions; printed material (brochures, pamphlets, banners, newspapers, magazines, books); electronic media (radio, TV); pilot farm as field practice, field meeting) and social activities (training and meetings).

The implementation of an innovation at the farmer/community based on the Diffusion Innovation Theory Everett M. Rogers (2003) in principle is that innovations are relatively easy to diffuse, appropriate, useful and uncomplicated. An innovation will be responded by the individual in accordance with the degree: its relative advantage, the compatibility, the complexity, the ability to be tried, and observability. The better the profit, its suitability, its simplicity and ease, the faster the technological innovation will be adopted.

The development of research related to communication networks has so far been generally limited to connecting communication networks with the adoption of innovations, was about the social network connection of farmers with the adoption of agricultural technology (Ramirez, 2013). Research conducted in southeast Texas shows the best ways to increase farmers' technology adoption, including using communication networks. Similar 
research results were also discussed by researchers from Indonesia (Cindoswari, 2012; Rangkuti, 2007). The results of research conducted by Cindoswari and Rangkuti showed the relationship between the communication network and each of the innovations raised by this researcher, among others, the innovation of cassava production technology and innovation of hand tractors. The study outlined above provides an overview related to the role of the communication network. However, the development of communication network research has so far still focused on its role in the adoption of innovation. According to Mudiarta (2009), there could be variations in the level of availability of social resources among individuals, groups, or in certain communities, which is dominated by the contribution of existing networks. Thus, the role of networks or social networks that grow in local communities is very likely to make a significant contribution to supporting the economic activities of their communities.

\section{LITERATURE REVIEW}

Diffusion as a process of spreading innovation through certain communication channels within a certain period of time to members of the social system (Rogers, 2003; Bass, 1969) in spreading new ideas can be through interpersonal channels and mass media (Berlo, 1960; Rogers \& Shoemaker, 1987). During this time, research on the success of adoption of an agricultural innovation is more highlighted by external factors or in this case, technological innovation factor and extension factor. Related to agricultural innovations, the previous research conducted on the adoption of agricultural innovations focuses more on things that are technically technical, economic or technological engineering. The results of the research conducted by Harinta (2011), Lalla et al. (2012), Putra and Warmika (2013), and Hosen (2014) showed that the competence and counselling skills in disseminating innovations among farmers are still one of the factors that influence the level of farmers' adoption of agricultural technology. Indraningsih (2016), Zulvera et al. (2014) and Eko (2010) showed that farmers still perceive high expectations of the extension activity and extension skills as communicators to improve their farming productivity.

Eko (2010) and Liu et al. (2005) stated that internal factors that are rarely discussed as a factor that influences the adoption of an innovation are actors and social structures for spreading innovation through interaction among members/actors while Eriyanto (2014) stated that in the network communication structure, the emphasis on the position of actors who play a role in the adoption of innovation is not on the structure or function of an organisation, but rather on each of the actors who are involved, be it farmers, extension worker, community leaders, or the citizen.

The actor's behaviour in accepting these new ideas was also influenced by his position in the network structure (Liu et al., 2005). Therefore, the structural properties of the network positioned affect the probability of recipient entity innovation. Structural characteristics of the network represent the main characteristics of a network that implicates how interactors interact in the network or with systems outside the network. Liu et al. (2005) identifies these features including centrality, constraint, range, density and embeddedness. In the context of the adoption and decisions of diffusion innovation, the characteristics of these network structures have different pathways in influencing the adoption of innovation, i.e. the pathway that affects innovative and pathways of the imitating behaviour. Centrality is a key property of actors in the network and becomes a structural measure of the importance of actors in the network (Freeman, 2004). Actors who 
have larger resources tend to have higher centrality and have greater contact intensity also in network structures (Liu et al., 2005).

The study outlined above provides an overview related to the role of the communication network. However, the development of communication network research has only focused on its role in the adoption of innovation.

Despite the position of an actor in the network affecting the adoption of an innovation, there are internal factors in the actors that make them decide to adopt and distort innovation. Ritzer and Stepnisky (2014) described it as a rational act of actors leading to a goal that ultimately resulted in certain actions including actions to adopt an innovation. Burt's (2004) statement in Rational Action Theory and also Coleman in Ritzer (2014) and Stepnisky (2014) state that their main barriers are (1) resources and (2) social institutions that provide positive and negative rejection that support certain actions and prevent they take other actions.

Based on the background and argument above, I have assumed that in the process of adopting technological innovations in planting technology Jarwo, in addition to external factors such as the characteristics of Jarwo innovation excellence, there are also internal influences associated with innovating actors in the structure of communication network. I believe that the actors are in a structured communication network structure, where the network is influenced by; first, the position and role of actors in the network, the breadth of the scope of actors in the network and network density as well as rational acts of actors in deciding and acting to adopt innovation; second, resources and access of information owned by actors. According to Setiawan (1983), the people who have many connections in the communication network tend to have great information and influence.

I believe that the formation of a communication network structure is based on individuals who communicate and connect with each other into groups that are subsequently connected to each other in a network because they have similarities and common interests. The communication network formed at the adopters was seen as a farmer's effort to obtain information on agricultural technology and assistance from various parties including the government. Communication network is important to analyse because in the adoption of innovation Jarwo, there is a condition describing the relationship between one actor and another in the network. Another important aspect of the study of the network is how structural regularity affects the behaviour of the actors.

The substance of research is about the relation concerning the base of communication connections between individuals and groups/organisations. Individuals who communicate with each other are connected to groups that are further connected to each other in the entire network. Thus, research on the network communication of farmers adopting technology Jarwo is to determine the phenomenon in general about the interaction of farmers in the social system and to identify the structure of the communication, including the role of each of the actors in the communication network.

\section{Innovation of Technology Jajar Legowo ("Jarwo")}

The innovation of technology Jarwo is an intermittent planting pattern between two or more (usually two or four) rows of rice plants and one empty line. The term Legowo is derived from the Javanese language. Legowo stands for the word "Lego" which means broad and the word "dowo" which means elongated. Legowo is also interpreted as a system of planting rice in paddy field which has several rows and is interspersed with one empty row. 
The application of Jajar Legowo, in addition to increasing crop population, is also able to increase the smooth circulation of sunlight and air around the edges of plants so that the plants can have better photosynthesis. In addition, plants that are on the margins are expected to provide higher production and grain of better quality. Since the Legowo planting system has an open space of $25-50 \%$, plants can receive sunlight useful for the photosynthesis process.

The purposes and objectives of the application of Jarwo system are, among others, to (1) utilise solar radiation in plants located at the periphery of the map, so it is hoped that the whole crop will have a border effect, (2) utilise the effect of air turbulence when combined with the irrigation system Wet-dried intermittent, so that it can remove soil organic acids harmful to the plant from the bottom to the top (evaporate), (3) increase the content of carbon dioxide ( $\mathrm{CO} 2$ ) and the results of crop photosynthesis, (4) facilitate the fertilisation and control of rats, and (5) increase the plant population per unit area. Jarwo as one of the technology components of the integrated plant Management approach (PTT) for rice paddy field can contribute to increased productivity of crop line crops (two or more) and rows it's empty (half-width on the right and left) which is called legowo unit. If there are two rows of planting per unit, then it is called legowo 2:1, while if there are four rows of cropping per unit, then it is called legowo 4:1, and so on.

Jarwo has been applied specifically in Cigasong District, Majelengka Regency. Farmers who have adopted the rice-planting technology Jarwo in Cigasong District, control $55 \%$ of the total planting area, including the most adopter farmers in Majalengka Regency. Jarwo adopters are scattered in all the villages with an area of $161 \mathrm{ha}$.

\section{Communication network}

Social networking is a set of people or groups of people with some form of contact and interaction between them (Scott, 2000). Communication networks are individuals connected with each other, which are linked by the flow of the patterned communication (Rogers \& Kincaid, 1981). Prell (2012) defines the network of communication as a set of relationships consisting of a group of "actors", in which there will be an exchange of information between actors in the relationship that is measured as relationship relations.

Rogers and Kincaid (1981) defines a network of communication as a research method to identify examined communications in the system, where communication flows are analysed using several types of interpersonal relationships as an analysis unit. The unit of analysis measured is the view and structure of communication. Wasserman and Faust (1994) and Crossley et al. (2009) defined a network definition of communication as an individual attribute to analyse the relationship between actors, how the actors are positioned in the network, and how the structure relationships in the pattern of the whole network. Wasserman measurement units are positions and relationships.

The power of the network refers to the power of actors and organisations included in the network that builds a global network of communities among a group of individuals (Castells, 2000). The study of communication networks illustrates the relationship of actors (can be people, institutions, companies, countries and so on) with each other in a particular social structure. There are two main keywords of network communication. First, the actor is a network of communication seeing the phenomenon or events of the micro aspect (actors). Second, relation; it means how the actors interact with each other. 
Eriyanto (2014) explains that the term communication networks or social networks are used at least for three different things. First, network communication as a technique of data analysis. Network analysis is used at the analysis stage, especially with the use of software social network data processors, such as UCINET, NodeXL, PAJEK, Phyton. Second, network communication as a method. The position of network analysis here is equivalent to experimentation, content analysis or survey method. Network analysis is not merely seen as a data analysis technique, but also a different method with other quantitative methods. Network analysis has a distinctive perspective, assumption, and data collection technique that distinguishes itself from other methods. Network communication here is seen as a research strategy in understanding the phenomenon or reality. The method of communication networks is different from the quantitative research methods widely known in communication studies.

Third, network communication as a theory. Communication or social networks can also occupy a position as a theory, a set of construction that connects and explains reality. Structural hole theory or weak ties (Degenne \& Forse, 1999) is a theory of communication/social network. Besides, the theory of communication network analysis is developed over time. Jacob Moreno was a psychology expert who first developed the theory of communication network analysis. Moreno examines how the individual's psychological condition is connected with social relations. Moreno and Jennings later developed how social relations affect individual psychological conditions and in this process they develop sociometric techniques. The sociometric technique uses quantitative methods to study group structure and individual position in the group (Moreno and Jennings in Rogers \& Kincaid, 1981; Prell, 2012). In this study, network communication was used as a basis for research methods and analysis of research data.

The methods and analysis of network communication have different characteristics with other research methods. According to Marin and Wellman (2011) in Eriyanto (2014), the important characteristic in the communication network method is the focus method on: (1) Relations and not the attributes inherent to actors by examining the various forms of actors (individual/individuals, agencies, countries and so on); (2) The research points to the assumption that actors are members or parts of a network and not groups; (3) The relationship between actors is understood in a particular relational context, meaning the position of actors is not independent, but is determined by the relationship with other actors in the network; (4) Actors and actor relationships on the network analysis are understood in a structural perspective, meaning the position of actors is determined by the position of other actors in the structure (Monge, 1987). Thus, the network analysis is structural by associating actors with other actors, actors with groups and actors with a whole system. Therefore, to learn the social structure of society is to analyse the pattern of relationships that connect its members.

Network analysis tries to illustrate the pattern and use of the network description to learn how the network structure restricts social behaviour and social change (Eriyanto, 2014). According to Monge (1987), the network structure that gives an opportunity at once can also restrict actors because the actor's position and actions are determined by the structural conditions in which the actor is located.

Rogers and Kincaid (1981) and Crossley et al. (2009) added that the purpose of the network analysis is to identify social structures. Therefore, network analysis can be defined as a quantitative method to analyse social structures and relationship patterns between actors in social structures that are represented visually in the form of sociograms. 
Communication network analysis is used by sociologists to analyse more about relationships and social interactions.

Analytical units in the communication network can be initiated from the smallest level, i.e. individuals, dyadic and triadics relationships, cliques to the network as the largest analysis unit. Rogers and Kincaid (1981) view the analysis of networks derived from convergent communication models where the information exchange between two individuals dyadic and related to personal communication networks, cliques or systems. Furthermore Rogers and Kincaid (1981) also classify the communication network analysis in five types of analytical units, namely individuals, personal communication, dyadic, cliques, and systems (networks).

Based on communication network analysis, researchers used the communication network analysis based on Monge and Contractor (2003), which is a complete networks on account of the fact that the phenomenon of farmers adopting the innovation of technology Jarwo is formed from three levels in its network, first; the actor's level focuses the researchers' attention on farmers as a central point for the formation of communication networks and the roles in the network formed, second; the group level focuses on the network formed of two or more farmers in the adopter Jarwo, where at this level, researchers can analyse the cohesivity of the group formed and the interactions formed in the farmer groups contained in the network, and why farmers formed the group, and third; level of system, researchers will focus on the network of communication of farmers an Jarwo's adopter which is related to the concept of density, distance and centralization of network structure formed that affects network cohesivity.

\section{Diffusion Theory of Innovation}

The main purpose of diffusing an innovation is the adoption of the innovation (science, technology, community development) by members of social systems. Social systems can be individuals, informal groups, organisations and the public. According to Rogers (2003), there are 4 (four) basic elements in the process of diffusing innovation, namely: an innovation, communicated through a particular communication channel, in a period and occurs among members of a social system. The main element consists of: (1) innovation (ideas, actions or goods) that a person considers new, (2) communication channels, is a tool to convey the message of innovation from the source to the recipient, (3) the time period, the process of innovation decision from the start of a person knowing to decide to accept or reject it, and (4) the social system is a collection of units that differ functionally and are tied in cooperation to solve the problem in order to achieve a common goal.

Acceptance or rejection of an innovation is a decision that a person receives in accepting the innovation. According to Rogers (2003), the process of innovation decision making is a mental process whereby a person passes from the first knowledge of an innovation by forming an attitude towards innovation, until it decides to refuse or accept, implementing new ideas and strengthening innovation decisions.

From experience in the field it turns out that the adoption process does not stop immediately after an innovation is accepted or rejected. This condition will change again as a result of the influence of the adoption environment. Therefore, Rogers (2003) revises his theories on decisions about innovation, namely: knowledge, persuasion, decision, implementation, and confirmation. 
The characteristic of diffusion innovation, where the characteristic of innovation is one that determines the pace of an innovation process. Rogers (2003) presents five characteristics of innovation, namely: relative advantage, compatibility, complexity, triability and observability.

Originally, the innovation diffusion theory has always been attributed to community development processes. Innovation is the beginning of social change, and social change is essentially the core of community development (Rogers \& Shoemaker, 1987). Social change is the process by which changes occur in the structure and function of social systems. Social change occurs in three stages, namely: (1) inventions, (2) diffusion, and (3) consequences. Discovery is the process by which new ideas are created or developed. Diffusion is the process by which new ideas are communicated to members of the social system, while consequences are a change in the social system as a result of the adoption or rejection of innovation.

Innovation diffusion theory is very relevant as the basis of research analysis of farmers' communication network that adopts the Jarwo when viewed from the diffusion of innovations that are the beginning of social change in community. In addition to mapping the result of communication network, farmers who adopt the Jarwo can answer how the network that is formed directly affects the diffusion of innovation.

\section{METHODOLOGY}

This research uses the post-positivism paradigm by using two quantitative and qualitative approaches. This approach is, according to (Bowen, 2009), a mutual analysis of quantitative and qualitative research (mutual analysis of quantitative and qualitative research). A quantitative approach was used in phase 1 where quantitative data was collected through: (1) surveys and the results of a numerical data from the collection of related primary and secondary data; (2) tabulation of data by matrix (sociometrics); and (3) the sociogram (UCINET 6). Phase 2 uses a qualitative approach meant to understand the common principles underlying the symptoms that become the center of research and the essence of the relationship between these symptoms with aspects of the life of the farmer community interviews.

The subject of this research is the farmer who implements Jarwo at Cigasong District Majalengka Regency of West Java. This research is conducted in Cigasong District. The study will be conducted for three months from September to December 2018. Population determination using a nominalist approach with two strategies for actors' identification are: positional and event-based, i.e. determining actors' populations based on participation or actors' involvement in certain positions and events, and is limited at any given time. So, the population in this research is a rice farmer who is a member of the farmer group that implemented Jajar Legowo planting technology within the last 2 years in Cigasong District.

Sampling is done using a small group of samples (Eriyanto, 2014), in the form of actors from all farmers who belong to the farmer group in Cigasong District with the criteria: (1) actors are rice farmers, (2) actors are farmers with the status of owner or lessee, (3) actors are farmers who have applied Jarwo for at least two years. The result of identification reveals that the number of samples reached 131 who are farmers adopting planting technology Legowo. They are from 10 villages in Cigasong District, namely Kawunghilir, Cigasong, Simpeureum, Tenjolayar, Karsway, Tajur, Cicenang, Baribis, Batujayam and Kutamanggu. 
Data collection includes: (1) pre-research interviews for the collection of demographic data, especially the names of the Jarwo adopter who will be the research informant drafted into the data roaster informant; (2) structured interviews (surveys), obtained by querying directly with the actors with the format of free recall; (3) in-depth interviews conducted after the survey procedure; (4) observation; researchers observed the investigated objects, and then observed the actors and relations between the actors. Questions on the questionnaire on the communication network are divided into five parts of the related communication events: (1) network communication information sources of Jarwo, (2) network communication on Jarwo discussion, (3) network communication decision of farmers to adopt Jarwo, and (4) network communication on problems of farmers against the Jarwo.

Analysis of network communication network structure in research focuses on complete networks analysis consisting of three levels of measurement, namely actors level, system level and group level. At the level of the actor, size is centrality, which refers to according to Freeman (2004), Valente (1996) and Prell (2012), how the position of each actor is in the entire network. The Level of the Group (group) that is in the analysis of network communication illustrates the cohesivity of the group interacting intensely referred to from Hanneman and Riddle (2005) with Borgatti and DeJordy (2013), while at the system level, communication network analysis analyses the entire network based on Monge and Contractor (2003), Carolan (2013), Borgatti and DeJordy (2013) and Valente (1996). For the validity of the research data carried out a validity test with triangulation testing namely: source triangulation; data collection techniques and triangulation data collection time.

\section{RESULT AND DISCUSSION}

Level of Structure

The results of this research showed that at the level of the structure of the communication network, farmers adopting technology Jarwo had a low cohesivity; size of the network is relatively large; low density; network structure is decentralized/spreading; and the average distance (path) between actors is quite high with a minimum distance of 1.39-2.55 steps. Referring to the typology of the communication network expressed by DeVito (1997), the Jarwo adopter communications network is dominated by the type of circle (Figure 1-4) with a network structure that is decentralised or spread.

The type of circle on the communication network of Jarwo adopters showed that almost all adopters have the same position in dissemination of information, no member of the network has the power to influence other members, generally members are only connected to a few other members and have an average connectedness in low cliques as not all members are interconnected in the communication network. In contrast, the cliques that are formed on the adoption of communications network of Jarwo adopter tend to form circles. This suggests that the interactions that occur are nothing dominant on a particular actor and all have the same opportunity to interact and give and receive information related to the adoption of Jarwo as well. 


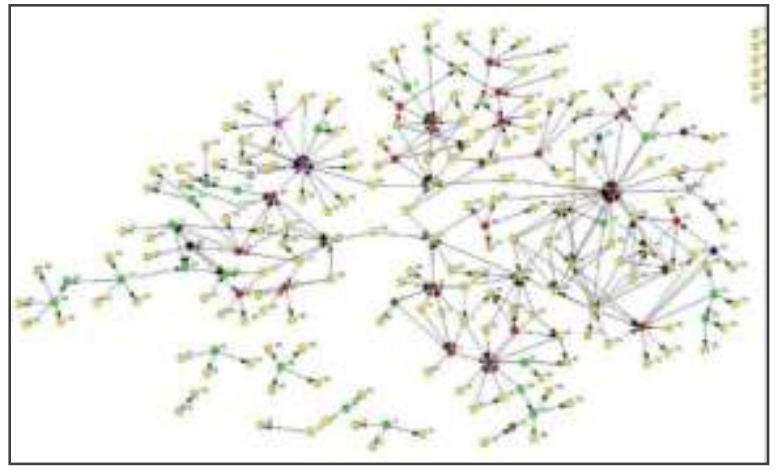

Figure 1: Communication networks: information source of Jarwo (IS)

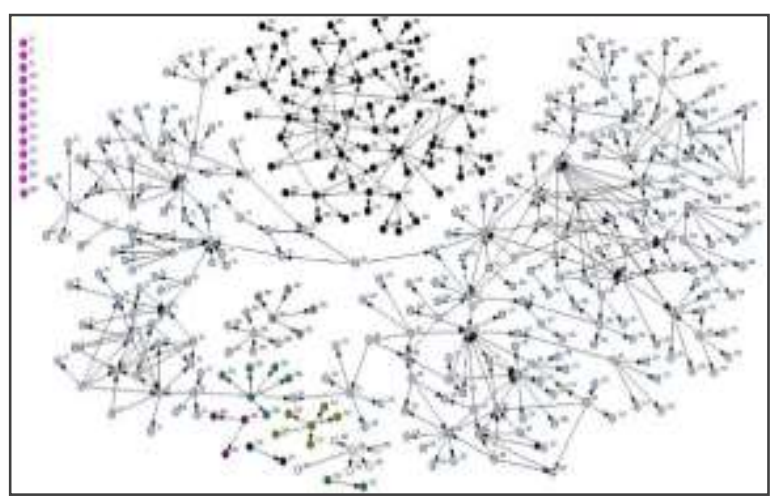

Figure 2: Communication networks: discussion of Jarwo (DJ)

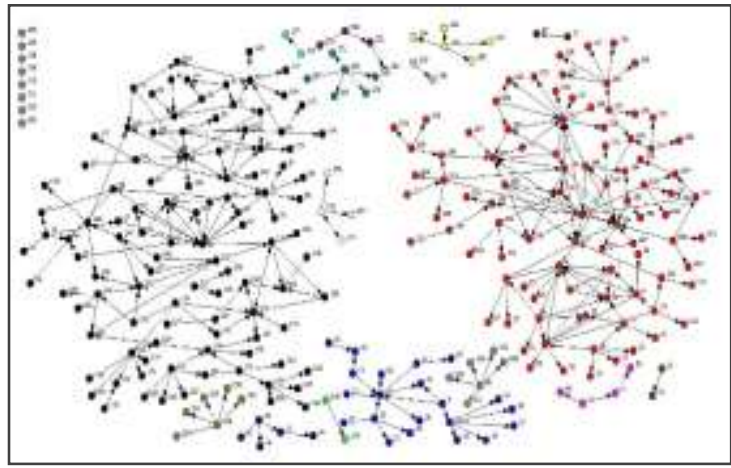

Figure 3: Communication networks: adoption of Jarwo (AJ)

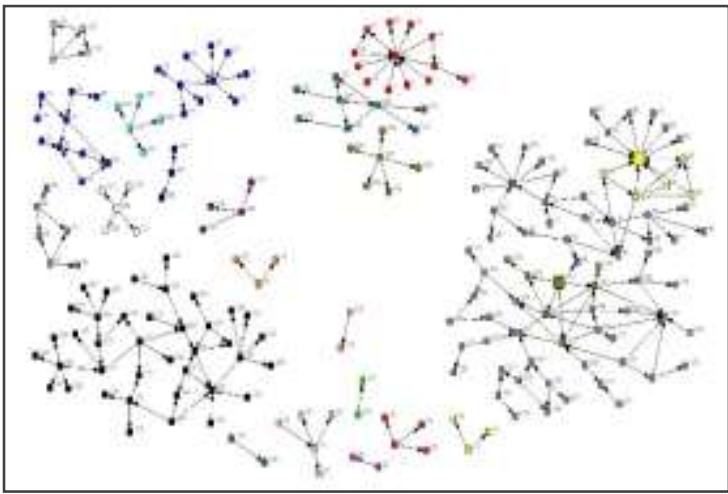

Figure 4: Communication networks: the problem of Jarwo (PJ)

\section{Level of Group}

Based on the findings of the researchers, it is known that the highest interaction was found on the Discussion Jarwo (DJ) Network by forming 56 circular-shaped cliques (Figure 5). This indicates that the highest interaction/relationship involving an adopter farmer is at the time of discussion about information of Jarwo. Based on the results of the interview known that the adopter while discussing the innovation of Jarwo has established a clique through to obtain the complete and clear information of Jarwo, therefore, the cliques is formed quite high. This is understandable because farmers desperately need trusted and convincing information from other farmers in the network to decide to apply Jarwo. 


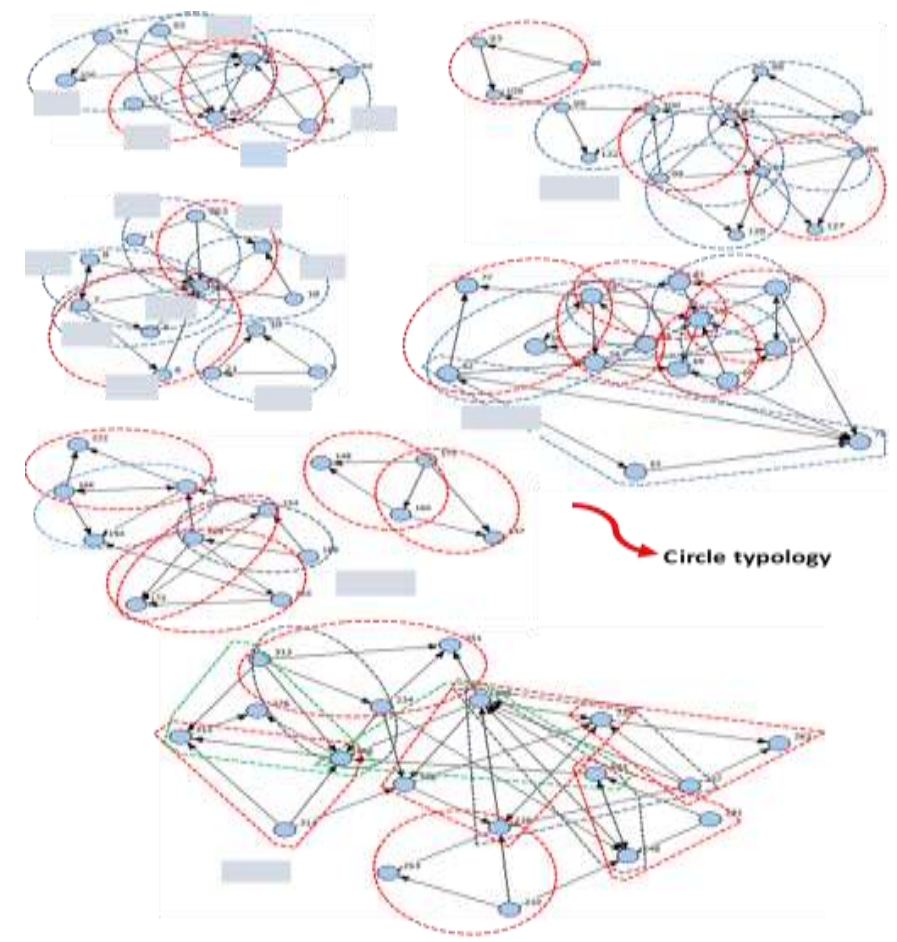

Figure 5: Clicks on Discussion of Jarwo Networks (DJ)

According to Rogers (2003), the innovation decision process is a process that a person (or other adoption unit) goes from starting to first know the innovation then responding, taking the decision to use (adopt) or reject it, and carry out the use of new ideas that the decision process innovation is an effort to obtain and process information in order to reduce uncertainty about innovation. At the discussion stage related to Jarwo's innovation technology information, the actors (farmers) are at the introduction or knowledge of Jarwo's innovations. Farmers mainly look for as much information about Jarwo, how the innovation works, how Jarwo can solve their problems and reduce the uncertainty of the introduced innovation. Therefore, it can be understood at this stage that there are quite a lot of cliques formed in the discussion network related to Jarwo's innovation, because farmers communicate to all actors / group members to the maximum.

The lowest clique form in this indicator is on the clique of the Problem of Jarwo (PJ) Network as many as 22 cliques, indicating that the adoption by an adopter farmer related to Jarwo problem is not as intense as discussing the preliminary information about Jarwo (Figure 6). Farmers can already solve Jarwo's related problems without interacting too much with fellow farmers. According to Bavellas (1950), research on a group of people on a network, groups of actors with circle type are the most uncentered clique and are the most irregular and unstable networks, and are shown to be at the latest breaking problem. However, Shaw in Tubbs and Moss (2000) argued that the network is not centralised (one of which is circular type) is better than centralised when faced with problems because it tends to cause composition in groups, increasing the power to think in the clique and not too dependent on the leader. 


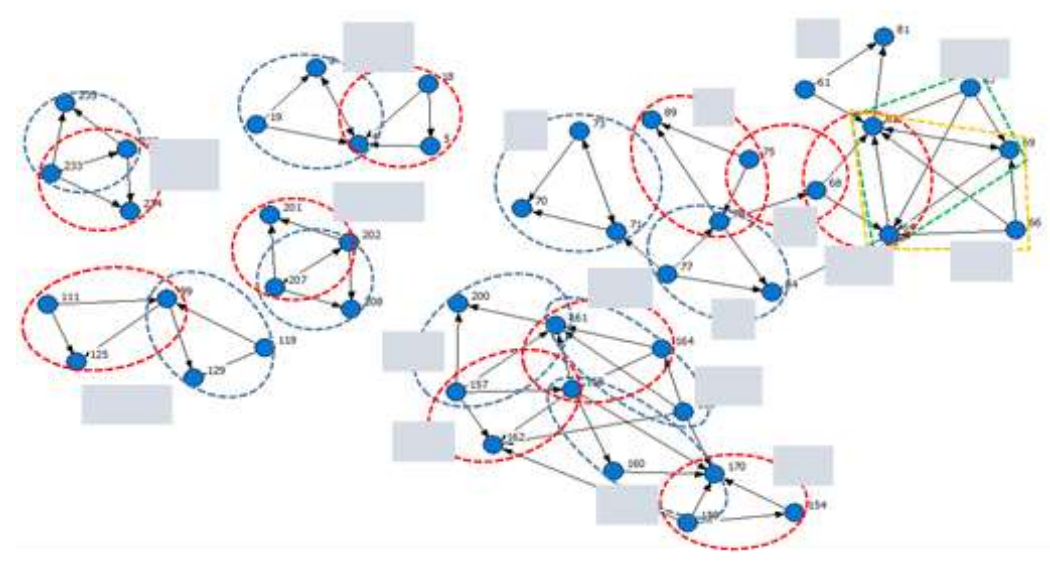

Figure 6: Clicks on Problem of Jarwo Networks (PJ)

The concept of homophile applies to clique on the Jarwo communication network, where actors converse with other actors who have similarities in certain characteristics, such as age, gender, education, prestige, social class, contracts, and employment. This finding is also in accordance with Hapsari (2016) in its research as homophile principles also apply to communication networks in social movements.

Further findings showed that the mass media that researchers assumed to be one of the factors adopted by Jarwo was not proven. The use of mass media is very low both print and electronic media and online media. This is contradictive to the research of Idris, Rosidayu and Mohd Yahya (2019) which states that radio, as one of electronic media, plays an important role in influencing farmers' problem recognition, involvement recognition, and referent criterion apart from reducing their constraints.

\section{Level of actors}

Communication Network: Information Source of Jarwo (IS)

Informant \#42 has a high level of value in outdegree centrality, closeness centrality and also betweenness centrality. Informant \#168 is closeness centrality in the network as well as has eigenvalue and informant \# 170 is betweenness centrality and eigenvector centrality. Actor \#42 is Baribis Village farmer and \#62 is an extension worker from Cigasong District and \#157 is a farmer at Simpeureum Village that belongs to the farmer group Nanggereng Simpeureum Village. The position of informant \#62 in accordance with their function is as the extension worker, where the informant often relates and communicates with other actors related to his work.

The first source of information related to Jarwo was obtained from the extension and leader of farmer group. But the position of informant \#157 becomes very interesting because in addition to acting as a liaison, the proximity of the informant with other actors makes the informant a so-called broker even if he does not have an important structural position in the village or group farmers. The results of interviews with the informant reveals that actor \#42 is a very influential farmer in Baribis Village. The role of closeness centrality and betweenness centrality is not separated from the status of informant \#42, formerly the officers of the Dinas Pertanian (Agriculture Office) of Majalengka Regency. Informant \#42 includes farmer innovators who first adopted Jarwo. 
Communication Network: Discussion of Jarwo (DJ)

The results showed that informant \#235 is the farmer of Simpeureum Village who has a betweenness centrality value and eigenvector centrality is quite high and quite influential in the discussion of Jarwo (DJ). This actor is very dominant as a reference source for actors in the communication network, and despite not having a closeness value with other actors in the network, closeness centrality is known to be owned by actor \#27 and \#28, which is extension worker of Cigasong District. This fact showed that farmers prefer to discuss Jarwos with their friends and the informant neighbours. They feel more comfortable to discuss Jarwo in the fields and farmers in the group meetings.

Communication Network: Adoption of Jarwo (AJ)

Informant \#191 who is a farmer in Simpeureum Village has a strategic role because with indegree value it means the informant provides much information, intermediaries and eigenvectors among actors in the network until finally other actors adopted Jarwo. Informant \#54 is a farmer in Baribis Village who is a public figure because of his role as a former employee of Dinas Pertanian (Agriculture Office) of Majalengka Regency. Another betweenness centrality in the network is informant \#120 who is the chairman of the farmer group in Jagabaya Kutamanggu Village; informant \#190 is a farmer from farmer group in Nanggereng Village; and informant \#4 is the chairman of the farmer group in Benda IV Batujaya Village.

\section{Communication Network: Problem of Jarwo (PJ)}

Informant \#62 and \#157 have a considerable role in the network and have indegree centrality, eigenvector centrality and also betweenness centrality in the network; the informant \#81 and informant \#84 have a closeness value in the network. This suggests that the actors are widely cited by other actors in the network. Informant \#63 acts as a mediator (betweenness centrality) and an interesting actor which is the only role in one centralization. Even though informant \#172 has a small value in the proximity (closeness), the actor has a role in the centrality of the outdegree as well as intermediaries.

It is revealed that informant \#62's profile is chairman of the farmers group in Jatidogdog of Cicenang Village; informant \#157 and \#158 are the farmer group's administrator and member of the farmers group in Naggerang of Simpeureum Village; Informant \#81-83 are farmers of Cicenang Village. It is known that farmers still rely heavily on the chairman of the farmer group in discussing problems related to Jarwo, while extension also still need farmers as a source of problem solving Jarwo.

\section{CONCLUSION}

The structure of the communication network of farmers adopting technology Jarwo had a low cohesivity; size of the network is relatively large; low density; network structure is decentralised/spreading; and the average distance (path) between actors is quite high with a minimum distance of 1.39-2.55 steps.

The highest interaction/relationship involving an adopter farmer is at the time of discussing about information of Jarwo. The adopter, while discussing the innovation of Jarwo, has established a clique-through enough to obtain the complete and clear information of Jarwo and therefore, the clique is formed quite high. The lowest clique formed in this indicator is on the clique of the Problem of Jarwo Network (PJ) indicating that 
the adoption of an adopter farmer related to Jarwo problem is not as intense as discussing the preliminary information about Jarwo.

The Actors who play an important role in "information sources" Jarwo are actor \#62 (extension worker) and \#42 who are farmers as betweenness centrality; on "Jarwo Discussion" and actor \#235 who is an actor with degree centrality and betweenness centrality role. It is known that actor \#235 is the farmer of the Simpeureum Village in the farmer group; while on the adoption of Jarwo network (AJ), actor \#235 plays a central role as an betweenness centrality and eigenvector centrality, while another influential actor is actor \#54 who is a public figure and actor \#120 who is the leader of the group. The result showed that an adopter farmer prefers to discuss Jarwo with his fellow farmers and the informant neighbours. In discussing the new technology, the informant feels more comfortable to discuss it in the fields and farmer group meetings. Based on the results of the interview with the informant \#235, it is known that the actors are influential enough and are widely referred to by other actors in the network.

\section{ACKNOWLEDGEMENT}

This research is a part of a doctoral project in the Faculty of Communication Sciences, Universitas Padjadjaran in Bandung, Indonesia. The case study is a part of a dissertation titled "The Communication Networks on Adopter Farmers of Jajar Legowo (Jarwo) Rice Planting Technology in Kecamatan Cigasong, Kabupaten Majalengka". This research receives grants from SMARTD Project (Sustainable Management of Agricultural Research and Technology Dissemination) through Indonesian Agency for Agricultural Research and Development (IAARD), Ministry of Agriculture. The researchers would like to express their gratitude to the IAARD and reviewers.

\section{BIODATA}

Vivit Wardah Rufaidah is PhD graduated from the Faculty of Communication Sciences, Universitas Padjadjaran Indonesia also a Librarian at Indonesian Center of Agricultural Library and Technology Dissemination (ICALTD), Ministry of Agriculture of the Republic of Indonesia. Email: vivitwardah@gmail.com

Asep Suryana is a lecturer of the Faculty of Communication Sciences, Universitas Padjadjaran, Indonesia. Email: asepsuryanakachya@yahoo.com

Dadang Sugiana is the Vice Dean of the Faculty of Communication Sciences, Universitas Padjadjaran, Indonesia. Email: dadang.sugiana@unpad.ac.id

Tuhpawana P. Sendjaja is the Professor in Agricultural Economy at the Faculty of Agriculture Universitas Padjadjaran, Indonesia. Email: tuhpawana.s@gmail.com 


\section{REFERENCES}

Bass, F. M. (1969). A new product growth for model consumer durables. Management Science, 15(5), 215-227.

Bavellas. (1950). Communication patterns in task-oriented groups. The Journal of the Acoustical Society of America, 22(6), 725-730.

BB Padi. (2014). Pusat penelitian dan pengembangan tanaman pangan dan balai penelitian tanaman padi. Retrieved from http://www.litbang.pertanian.go.id

Berlo, D. K. (1960). The process of communication: An introduction to theory and practice. NY: Holt Rinehart and Winston Inc. Press.

Borgatti, S. P., \& DeJordy, R. (2013). Basic concepts in sosial network analysis (Paper on The Workshop SNA, 5 Juni 2013).

Bowen, G. A. (2009). Document analysis as a qualitative research method. Qualitative Research Journal, 9(2), 27-40. https://doi.org/10.3316/QRJ0902027

Burt, R. S. (2004). The social structure of competition: Network and Organization (Chap. 2, pp. 57-69). Retrieved from https://www.semanticscholar.org/paper/The-SocialStructure-of-CompetitionBurt/38f8f1767e2680b77480b3ca3d7d34597eb204b2\#paper-header

Carolan, B. V. (2013). Social network analysis and education: Theory, method and application. Thousand Oaks: Sage Publication.

Castells, M. (2000). Toward a sociology of the network society could not be. Contemporary Sociology, 29(5), 693-699.

Cindoswari, A. R. (2012). Jaringan komunikasi dalam penerapan teknologi produksi ubi kayu (Kasus petani ubi kayu di Desa Suko Binangun, kecamatan Way Seputih, kabupaten Lampung Tengah, provinsi Lampung). Jurnal Komunikasi Pembangunan, 10(2).

Crossley, N., Prell, C., \& Scott, J. (2009). Social network analysis: Introduction to special edition. Methodological Innovations, 4(1), 1-5.

Degenne, A., \& Forse, M. (1999). Introducing social networks. Thousand Oaks: SAGE.

DeVito, J. A. (1997). The interpersonal communication book. US: Addison-Wesley.

Eko, M. (2010). Strategi komunikasi dalam penyuluhan pertanian dengan M vendor (Suatu pendekatan komunikasi kelompok dan interpersonal). SEPA: Jurnal Sosial Ekonomi Pertanian dan Agribisnis, 6(2), 69-77.

Eriyanto. (2014). Analisis jaringan komunikasi: Strategi baru dalam penelitian ilmu komunikasi dan ilmu sosial lainnya. Kota Jakarta: Prenada Media Grup.

Freeman, L. C. (2004). The development of social network analysis: A study in sociology of science. Empirical Press.

Hanneman, R. A., \& Riddle, M. (2005). Introduction to social network methods. Riverside, CA: University of California.

Hapsari, D. R. (2016). Peran jaringan komunikasi dalam gerakan sosial untuk pelestarian lingkungan hidup. Jurnal Komunikasi Ikatan Saraja Komunikasi Indonesia, 1(1), 2536.

Harinta, Y. W. (2011). Adopsi inovasi pertanian di kalangan petani di Kecamatan Gatak Kabupaten Sukoharjo. Jurnal Agrin, 5, 164-174.

Hosen, N. (2014). Peranan LKM-A dalam mendorong percepatan adopsi teknologi jagung di Sumatera Barat. Jurnal Penelitian Pertanian Terapan, 14(1), 22-30.

Indraningsih, K. S. (2016). Pengaruh penyuluhan terhadap keputusan petani dalam adopsi inovasi teknologi usahatani terpadu. Jurnal Agro Ekonomi, 29(1), 1-24. 
Indraningsih, K. S. (2018). Strategi diseminasi inovasi pertanian dalam mendukung pembangunan pertanian. Forum Penelitian Agro Ekonomi, 35(2), 107-123.

Idris Ismail, Rosidayu Sabran, \& Mohd Yahya Mohamed Ariffin. (2019). The role of radio in problem solving on the perceptual situation to the insufficient information delivery for Malaysia's agricultural extension services. Jurnal Komnikasi: Malayasian Journal of Communication, 35(2), 331-345.

Lalla, H., Ali, M. S. S., \& Saadah. (2012). Adopsi petani padi sawah terhadap sistem tanam jajar Legowo 2:1 di Kecamatan Polongbangkeng Utara, Kabupaten Takalar. Jurnal Sains \& Teknologi, 12(3), 255-264.

Liu, B. S.-C., Madhavan, R., \& Sudharshan, D. (2005). DiffuNET : The impact of network structure on diffusion of innovation. European Journal of Innovation Management, 8(2), 240-262. https://doi.org/10.1108/14601060510594701

Monge, P. R. (1987). The network level of analysis. In C. R. Berger \& S. H. Chaffe (Eds.), Handbook of Communication Science. Thousand Oaks: Sage Publication.

Monge, P. R., \& Contractor, N. S. (2003). Theories of communication networks. Oxford: Oxford University Press.

Mudiarta, K. G. (2009). Jaringan sosial (networks) dalam pengembangan sistem usaha agribisnis: Perspektif teori dan dinamika studi kapital sosial. Forum Penelitian Agro Ekonomi, 6(2), 1-12.

Prell, C. (2012). Social network analysis: History, theory and methodology. Thousand Oaks: SAGE.

Putra, I. G. A. G., \& Warmika, G. K. (2013). Analisis komparatif karakteristik demografi dalam mengadopsi smartphone di Kota Denpasar. E-Jurnal Manajemen, 2(9), 1141-1159.

Ramirez, A. (2013). The influence of social networks on agricultural technology adoption. In Procedia - Social and Behavioral Sciences, 79, 101-116. https://doi.org/10.1016/j.sbspro.2013.05.059

Rangkuti, P. A. (2007). Jaringan komunikasi petani dalam adopsi inovasi teknologi pertanian (Kasus adopsi inovasi traktor tangan di Desa Neglasari, Kecamatan Bojongpicung, Kabupaten Cianjur, Propinsi Jawa Barat). MT - Human Ecology [1525]. Retrieved from http://repository.ipb.ac.id/handle/123456789/9857

Ritzer, G., \& Stepnisky, J. (2014). Sociological Theory. US: McGraw-Hill.

Rogers, E. M. (2003). Diffusion of innovation (5th ed.). NY: Free Press.

Rogers, E. M., \& Shoemaker, F. F. (1987). Communication of innovations: A cross-cultural approach. NY: Free Press.

Rogers, E. M., \& Kincaid, D. L. (1981). Communication networks: Toward a new paradigm for research. NY: Free Press.

Scott, J. (2000). Social network analysis: A handbook (2nd ed.). Thousand Oaks: SAGE.

Setiawan, B. (1983). Metode analisis jaringan komunikasi: Seri metodologi penelitian. Yogyakarta: Seksi Penerbitan Fakultas IImu Sosial dan Ilmu Politik Universitas Gadjah Mada.

Syakir, M. (2016). Consolidation of innovation and dissemination of technology in empowering farmers. Prosiding Perlindungan dan Pemberdayaan Pertanian dalam Rangka Pencapaian Kemandirian Pangan Nasional dan Peningkatan Kesejahteraan Petani (pp. 3-14).

Tubbs, S. L., \& Moss, S. (2000). Human communication. NY: Mc-Graw Hill.

Valente, T. W. (1996). Social network thresholds in the diffusion of innovations. Social Networks, 18(1), 69-89. 
Wasserman, S., \& Faust, K. (1994). Social network analysis: Methods and applications. Cambridge, UK: Cambrigde University Press.

Zulvera, Sumardjo, Slamet, R. M., \& Sugihen, B. G. (2014). Faktor penentu adopsi sistem pertanian sayuran organik dan keberdayaan petani di provinsi Sumatera Barat (Dissertasi, IPB: Bogor Agricultural University, Indonesia). DT - Human Ecology [386]. Retrieved from http://repository.ipb.ac.id/handle/123456789/70102 